Helgoländer wiss. Meeresunters. 17, 476-488 (1968)

\title{
Surface pollution and light extinction in the Oslofjord
}

\author{
Hans Munthe-KaAs \\ Norwegian Institute for Water Research, Oslo, Norway
}

KURZFASSUNG: Oberflächenverunreinigung und Lichtextinktion im Oslofjord. Die Wasserverschmutzung bildet ernste Probleme im Hinblick auf die Bedeutung des Oslofjords als Erholungsgebiet. Diese Probleme sind bisher nicht untersucht und durch das Oslofjord-Projekt (1962-1965) nur fragmentarisch behandelt worden. Verschiedene Unannehmlichkeiten sind zu nennen, welche die Wassertrübung und Wasserfärbung, Treib- und Strandgut, Geruch, Wachstum und Humusbildung am Strand, verringerte Fischereimöglichkeiten sowie verschlechterte hygienische Bedingungen betreffen. Transparenz, Turbidität und Färbung werden als Funktion von Position und Jahreszeit diskutiert; die Abhängigkeit der Transparenz von Turbidität und Färbung wird mittels einer Regressions-Analyse dargestellt. Zum Schluß werden Möglichkeiten zur Verbesserung des gegenwärtigen Zustandes erörtert.

\section{INTRODUCTION}

\section{Background}

In regard to the pollutional problems of the Oslofjord there are three groups of problems to be dealt with: (A) quality criterias and quality standards, (B) causes of quality deterioration, and (C) means of quality improvements.

The recently completed Oslofjord research project was primarily concerned with group (B). From hydrographical, chemical and biological studies and through a survey of the pollutional substances discharged into the fjord, a fairly good knowledge of the dynamics of the fjord was obtained. Based upon the results from (B), answers to group (C) have been given as a list of possible means of improvements.

As group (A) was not part of the original project plan, the research here was only of minor extent. The fragmentary investigations carried out received limited attention and were of modest quality and thoroughness. Despite this, the work which concerns this group is reported here, as it indicates various questions - both general and specific to the Oslofjord - which need to be elucidated in the future. The results moreover seem to be of scientific interest.

\section{Scope}

Complaints on the conditions of the Oslofjord have various aspects, although it is difficult for people to define just what the nuisances are. The main objections may be 
grouped as follows: (a) Reduced water transparency in the surface layer, (b) floatables on the surface (rubbish, drifting seaweeds, oil etc.), (c) beach rubbish etc., (d) growth in the beach region (algae, shellfish etc.), (e) odour, (f) black mould formation on the beaches, and $(\mathrm{g})$ reduced fishing possibilities. In addition, a general feeling of hygienic insecurity (h), and of esthetic dislike (i), is usually connected with the thought of pollutional phenomena and their origins. Finally, it may be mentioned that many people object to all disturbing of the unspoiled nature (j).

The spectrum of nuisances shown was subjected to investigations as follows: (a) Water transparency in the surface layer, which is a function of turbidity and filtrate colour, was surveyed - though in part only sporadically - for 4 years. Transparency measurements (Secchi disc) were the main method, but also a certain amount of turbidity and filtrate colour measurements were conducted. The dependency of the Secchi disc values on turbidity and filtrate colour was evaluated through statistical calculations. The causes of the variations in turbidity and filtrate colour were discussed. (b) and (e) Floatables on the surface and odour were recorded for one year. (c), (d) and (f) Nuisances in the beach region were not measured quantitatively but studied during a test panel experiment in 1964. (g) Pollution influences on fishing possibilities were considered in one of the original project investigations and will be reported separately. (h) Hygienic aspects of pollution have not been the object of special investigations in connection with the project. The project report, however, includes a general view given by the Central Norwegian Health Authorities. (i) and (j) Considerations separately concerning esthetics or nature protection were not included in the project.

\title{
INVESTIGATIONS AND RESULTS
}

\author{
Transparency of the water
}

\section{Data}

Four separate series of measurements contribute to the survey of water transparency: (1) The basic hydrographical and chemical field programme of the project, with a cruise frequency of about 15 per year through 4 years, was carried out at 12 sampling stations (Fig. 1a). Secchi depth and turbidity were measured through the entire period, and the filtrate colour through the last 2 years. (2) A minor field programme carried through from 1964 to 1965 in order to survey the cross section gradients of the fjord (Fig. 1b) included Secchi depth measurements. (3) A total of seven summer cruises were made during a special surface programme in 1963,1964 and 1965. Samples were taken from 72 to 150 fixed locations (Fig. 1c); Secchi depth was one of the parameters. (4) Secchi depth measurements were also included in another minor field programme in order to study variations in water masses between regular cruises.

For various reasons the accuracy of Secchi depths and turbidity measurements was not high. Filtrate colour measurements were more precise, but they had the drawback of representing only one wavelength (4250 $\AA$ ). 

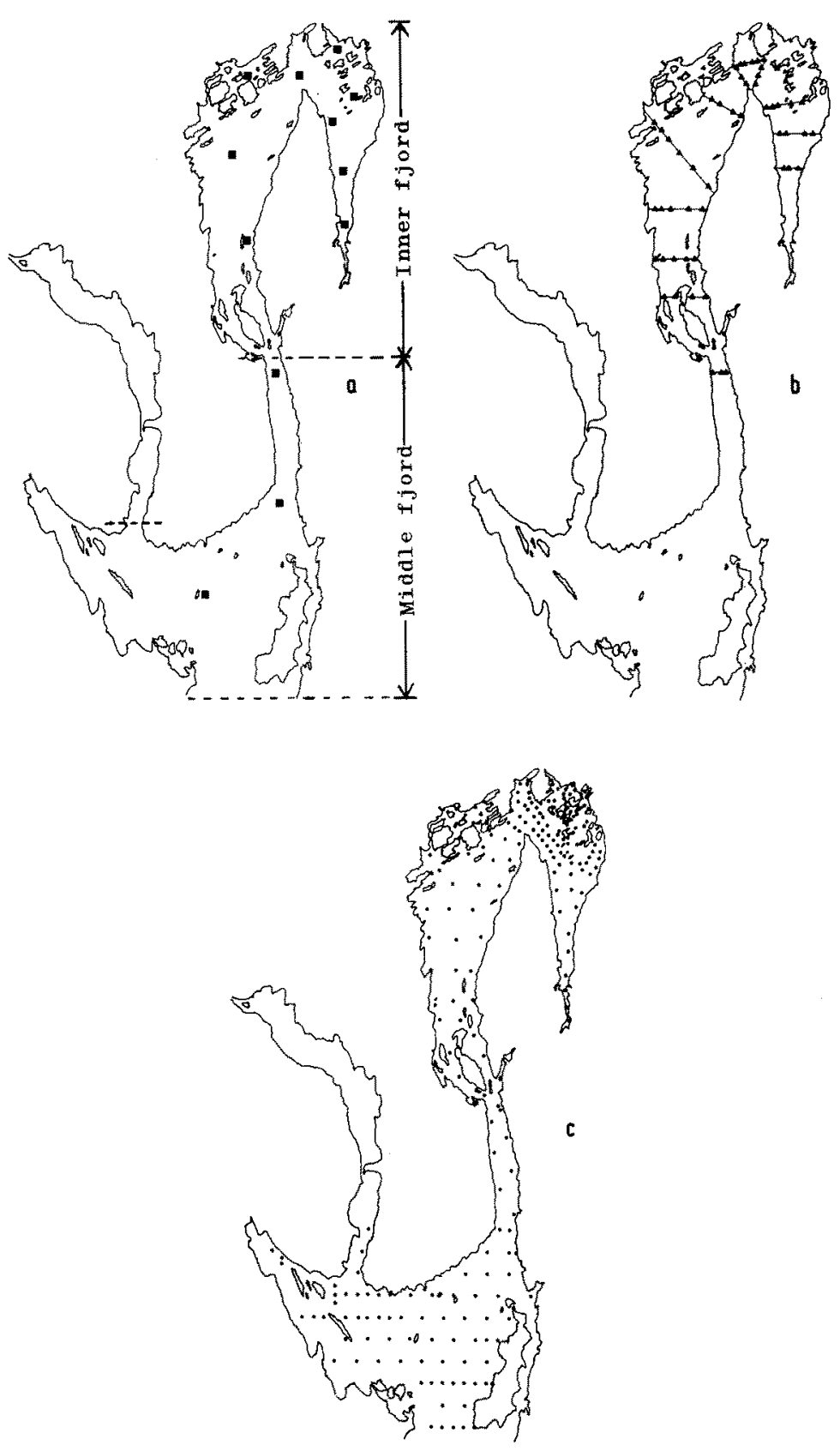

Fig. 1: Sampling stations for (a) basic hydrography, (b) cross section hydrography, (c) surface hydrography 


\section{General patterns of variation}

As expected, the seasonal variations of Secchi depths appeard to be considerable. In the open water of the inner fjord average values were as follows (averages of 550 measurements, 1963, 1964 and 1965):

$\begin{array}{llll}\text { December/January } & 7.05 \mathrm{~m} & \text { June/July } & 2.99 \mathrm{~m} \\ \text { February/March } & 4.37 \mathrm{~m} & \text { August/September } & 3.10 \mathrm{~m} \\ \text { April/May } & 3.06 \mathrm{~m} & \text { October/November } & 4.85 \mathrm{~m}\end{array}$

The seasonal pattern was however about the same for the more protected waters in the inner and middle fjord.

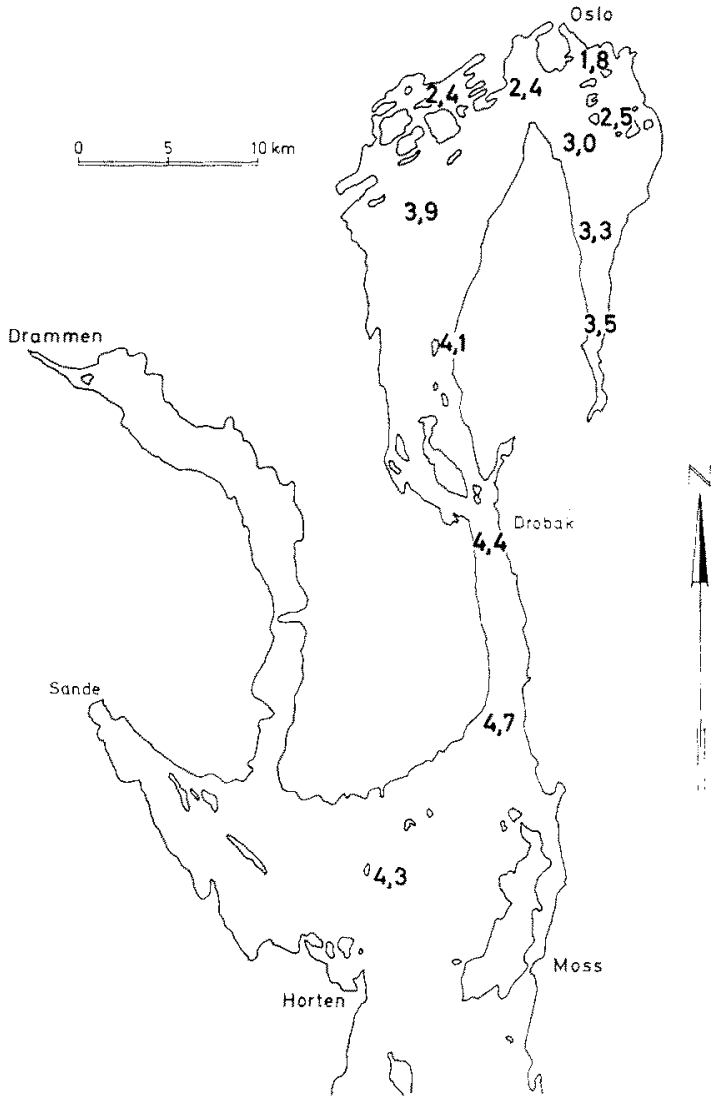

Fig. 2: Secchi depths (in m) in June/July, averages for the period 1962 to 1965

The geographical Secchi depth gradient varied throughout the year; the highest appearing in February/March and August/September, the lowest in April/May and in October/November. Figure 2 shows the average June' July value from the 12 main stations. 


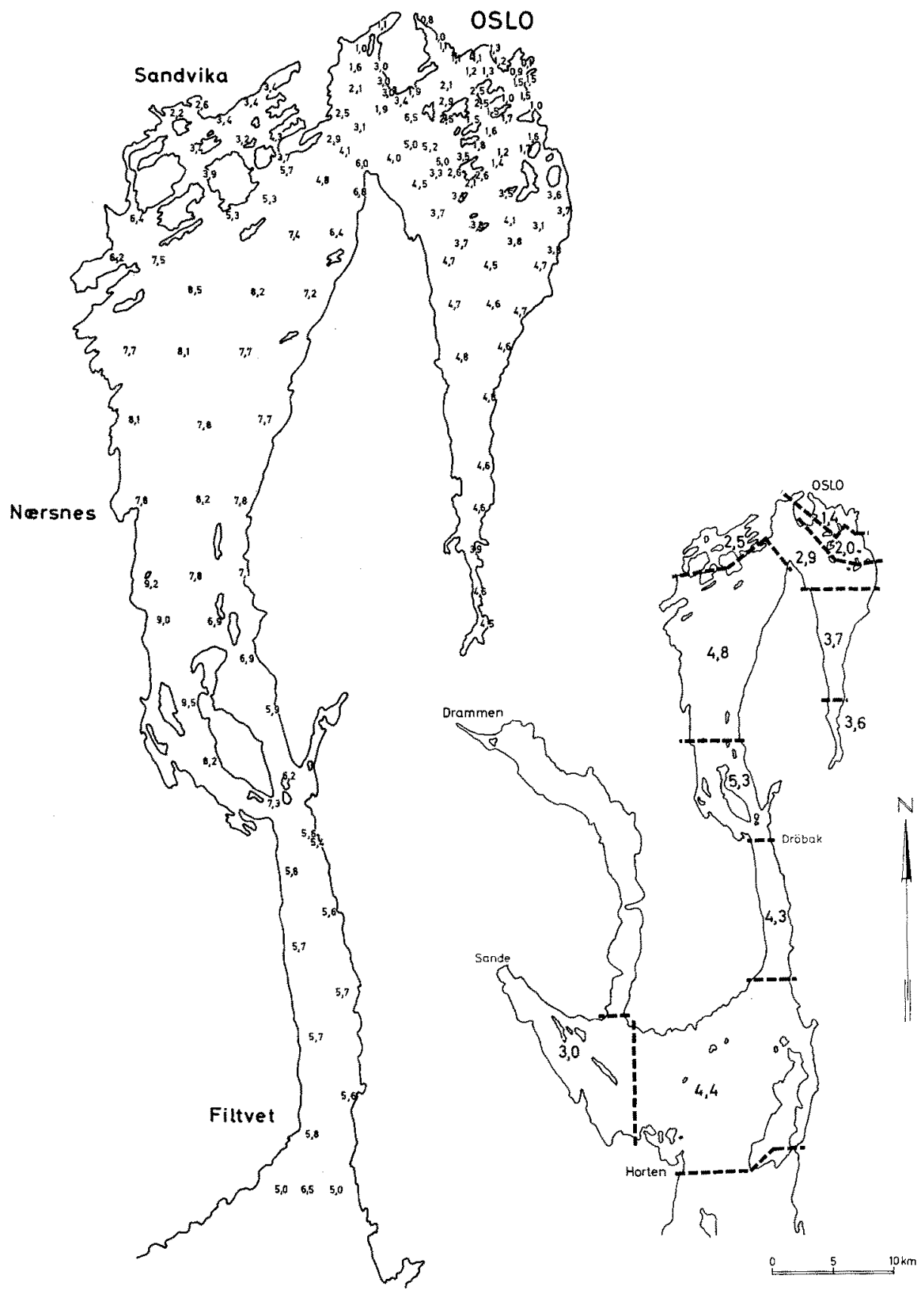

Fig. 3a: (left) Secchi depth measurements (in m) conducted on August 17, 1965

Fig. 3b: (right) Secchi depths (in $\mathrm{m}$ ) measured in June/July 1965. Zone averages based on stations in Figure 1c 
The extreme algal growth, causing a large reduction of Secchi depths, and consequently regarded as a major nuisance by the public, had previously been observed in the fjord during the summer; however, during the project period these phenomena only appeared in autumn.

\section{Local variations}

Local variations of Secchi depths have proved interesting and important.

Great differences in Secchi depths have often been observed simultaneously at close neighbouring stations (Fig. 3a), and within narrow time intervals in the same positions. This phenomenon is thought mainly to be a consequence of local winds and currents.

Observations from the 150 surface stations indicate that, in regard to Secchi depths, the inner fjord is not essentially inferior to the middle fjord. The major factors seem to be local conditions in regard to varying degrees of protection from the open sea and the amount of pollutant substances discharged into the area (Fig. 3a, b). The latter is based mainly on average values from the summer of 1965 . Each value shown represents all surface stations in the zone.

The highest summer transparency in the inner and middle fjord was normally found north of Drøbak, especially in the western sound; and not, as expected, in the middle fjord. The lowest values were found in the Oslo harbour area and in narrow bays in the northern part of the fjord. The extreme all year single values $(19 \mathrm{~m}, 0.3 \mathrm{~m})$ were both measured in late autumn in the central inner fjord.

Along the cross sections, distinct Secchi disc gradients have been observed only in the northern end of the fjord - the lowest values on the city side. On an average the west fjord showed a weak gradient, increasing westwards, while the Bunnefjord showed no consistent gradients.

\section{Factors influencing transparency}

The Secchi depths depend for the most part on the particle content and filtrate colour of the water. As pure water itself absorbs light to a certain degree, there is a theoretical maximum Sechi depth; by a Japanese named NAunITI it has been calculated to be $173 \mathrm{~m}$ (STRICKLAND 1958). The maximum depth observed in practice is approximately $60 \mathrm{~m}$. In the Skagerrak values between 7 and $16 \mathrm{~m}$ normally has been found (KRÜMMEL 1907).

In regard to our method of Secchi depth measurements, various interfering factors will be of significance, such as light conditions (sun elevation and clouds) and wind forces (wave effects). The subjective judgment of the person measuring is considered also to be an important factor.

By means of a regression analysis an attempt has been made to find the relative importance to Secchi depth values of turbidity, filtrate colour, wind, sun elevation and cloud cover. The analysis was based upon 294 sets of data, which all included 


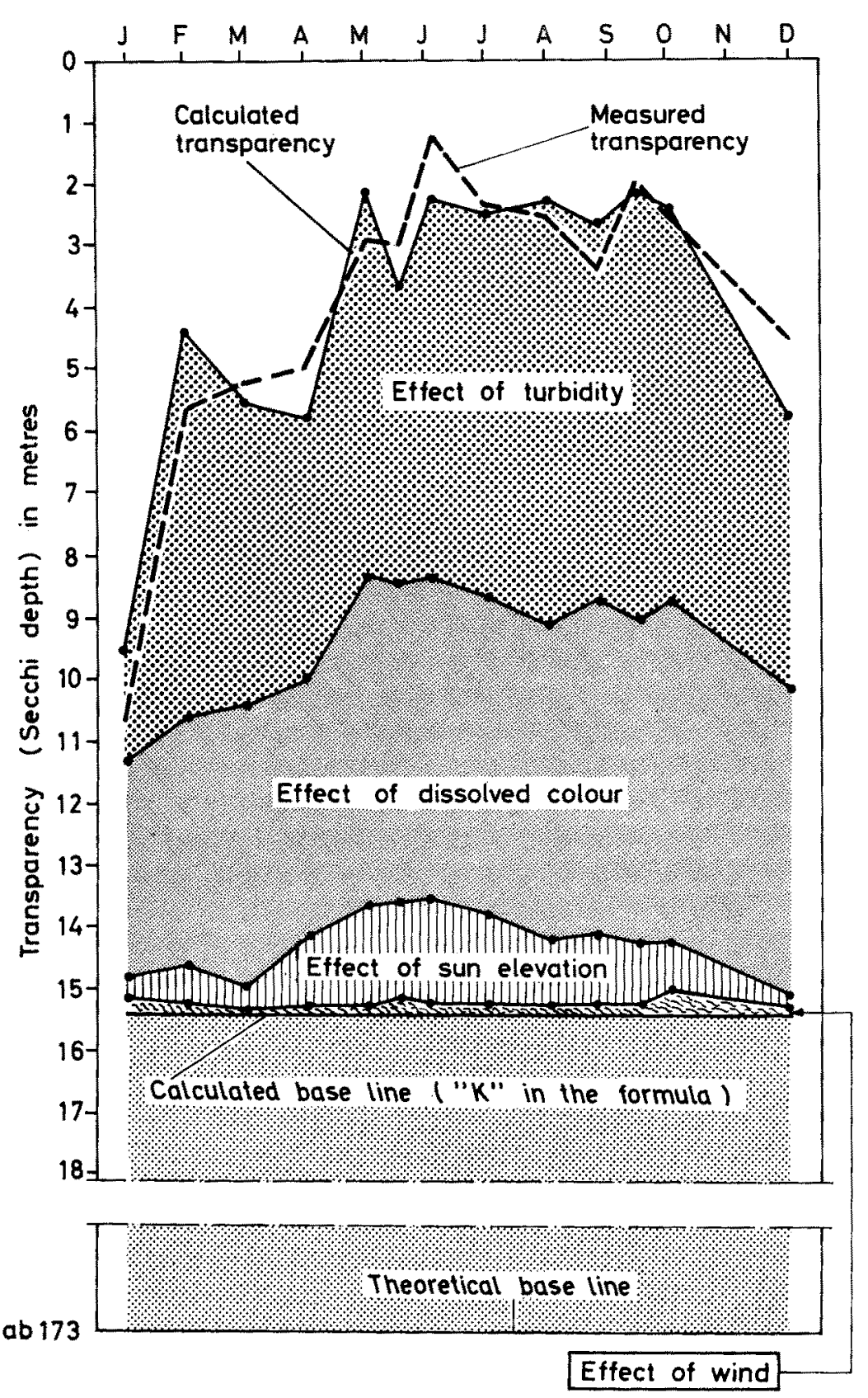

Fig. 4: Major factors influencing transparency of the surface water as measured by the Secchi disc. (Based on formula [1] and the data from one of the inner stations [Bn 1] in 1964) 
the factors mentioned. The mathematical method applied for the analysis was quite simple and included some simplifications of the problem. A more precise approach was considered difficult with the limited expertise available and, moreover, not justified by the data. The result obtained has, however, confirmed that the analysis was adequate for the problem in question.

Among the simple regression formulas applied - all gave about the same degree of precision - a type was selected using the variables exclusively in an explicit form. This does not reflect the physical realities in the best way, but offers some advantages in practical application.

The formula was:

$$
S=f(T)+f(F)+f(W)+f(S)+f(C)+K
$$

where

$$
\begin{aligned}
& \mathrm{S}=\text { The Secchi depth } \quad \mathrm{W}=\text { Strength of wind } \\
& \mathrm{T}=\text { The turbidity } \quad \mathrm{S}=\text { Sun elevation } \\
& \mathrm{F}=\text { The filtrate colour } \quad \mathrm{C}=\text { Cloud cover } \\
& \mathrm{K}=\mathrm{a} \text { constant }
\end{aligned}
$$

A practical example, based upon 2 years of observations at one station, demonstrates the results of the analysis (Fig. 4). The diagram shows observed and calculated Secchi depths, and the contribution of the various factors considered. The validity of the formula is restricted to the regions of 0.5 to $4 \mathrm{mg} \mathrm{SiO} / 1$ of turbidity and 5 to $20^{\circ}$ Hazen of filtrate colour - which explains the big gap between theoretical and calculated base lines in the diagram. The primary purpose of developing this formula will be explained later (p. 487).

\section{Causes of turbidity}

It is assumed, and probably correctly, that the turbidity of the Oslofjord during the period February to October is due primarily to planktonic algae. The erosional particles from the rivers are supposed to be only locally important. Although in flood periods they may be seen throughout the entire fjord, at the end of the flood periods these particles disappear again. Particulate sewage components are assumed to be precipitated or dissolved rapidly and, consequently, remain restricted to the neighbourhood of the outlet.

No measurement or estimate has been made as to what extent turbidity may be influenced by phytoplankton and other materials. An indirect method which might give such information is however now being tested. The method - a regression analysis - may be applied to samples where the individual number (p) of each of the approximately. 175 phytoplankton species found during the studies and the turbidity $(T)$ are known. The regression formula (2) is as follows:

$$
\mathrm{T}=\mathrm{x}(\mathrm{L}, \mathrm{S})+\mathrm{f}(\mathrm{T}) \cdot \Sigma \mathrm{a}_{\mathrm{i}} \cdot \mathrm{p}_{\mathrm{i}}
$$

the unknown variables are: $x(L, S): x=$ effect of turbidity not caused by phytoplankton ( $x$ is assumed to be a function of location in the fjord [L] and season of the 
year $[\mathrm{S}] ; \mathrm{a}_{\mathrm{i}}$ : the optical dimension of phytoplankton species number "i"; $p_{1}$ : the number of individual cells of phytoplankton species number " $i$ "; $f(T):$ a correction factor representing a possible non-linearity between turbidity and number of particles. The value of $f(T)$ is assumed to be close to 1 in the actual region.

In principle, this method is expected to be useful; but whether the limited number of data available from about 350 samples will give useful results is not yet known.

\section{Causes of filtrate colour}

On the base of material budgets, the measured filtrate colour in the surface layer of the fjord seems to be caused mainly by natural colour components dissolved in the inflowing river water. These colour components seem to have a slow rate of decay in the sea. 'The dissolved colour components originated from sewage seem to be important only locally but not in the open fjord.

In the deep water of inner fjord basins large amounts of dissolved colour components seem to develop as the product of organic decomposition. These colour components have apparently a rapid decay rate. Due to the fairly effective exchanging of middle depth water between the inner and the outer fjord, and to the restricted vertical diffusion through the pycnocline, only minor amounts of it will probably contribute to the supply of surface water colour.

\section{Floatables and odour}

To estimate the importance and magnitude of floatables and odour in the fjord, a minor survey was carried out in 1965 . When the boats on cruises arrived at the established sampling stations, odour and floatables momentarily noticeable within a radius of $30 \mathrm{~m}$ were recorded. The floatables were classified into four groups: solid objects, rubbish, drifting seaweeds and oil patches. The entire survey covered approximately 1000 station visits. The precision of the observations was not very high, and the results obtained should be taken only as an indication. Figure 5 shows recordings averaged for all four groups of floatables, the zones and the year 1965. The result was rather surprising, as the frequency of findings was much less in the inner than in the middle fjord (about $5 \%$ versus about $20 \%$ ). The distribution of findings between the four groups was nearly the same for the entire fjord; within each zone, however, major differences appeared.

The findings indicate that floatables do not create a serious problem in the open part of the fjord; it should be noted, however, that our observations do not include the waters close to the shore, where the frequency would undoubtedly have been considerably higher. In regard to the recreation qualities, this is important, since conditions at the beach and in the harbour region are more important to the public than the conditions in the open fjord.

Considering the odour, no bad smell was recorded when visiting the regular sampling stations; this does not exclude existence of bad odour in local fjord areas, 
especially near sewage outlets, but it indicates that bad odour is not a normal phenomenon in any of the areas covered by our stations.

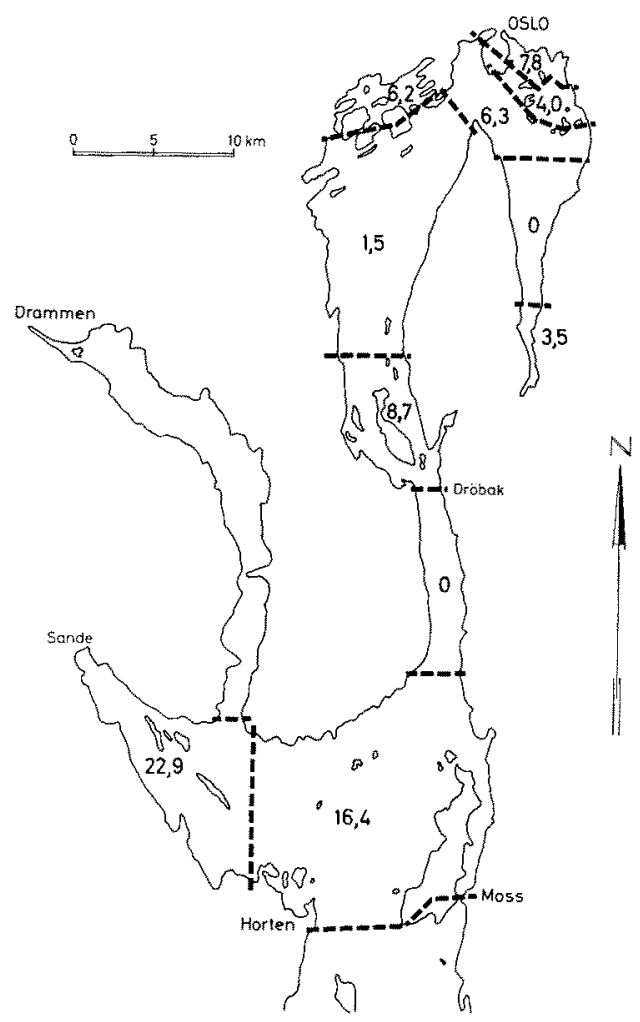

Fig. 5: Floatables; frequency of findings in per cent

\section{Nuisances on the beaches}

In order to try a method for examining the beach regions, 15 nearby associations, institutions, etc. especially interested in the fjord were invited to join three test panel tours to seven commonly used bathing resorts in the northern part of the inner fjord.

During the tour, each participant should write his personal judgment of the beach quality down on a questionnaire. No guidance regarding quality criterias and standards were given. All phenomena bearing on the beach quality were to be considered, whether they were thought to be consequences of pollution or not.

The defined purpose of this investigation was to study: (1) the esthetic and recreational quality of the beach region as evaluated by the public, (2) to what extent public judgment corresponds with that of the project staff, (3) the quality standards of the various beaches, (4) how much each of the various phenomena means to the public. 
The panel data were examined by statistical methods, although the number of data was, naturally, too small to give dependable results. Nevertheless, investigations of this kind seem useful and easily accomplishable.

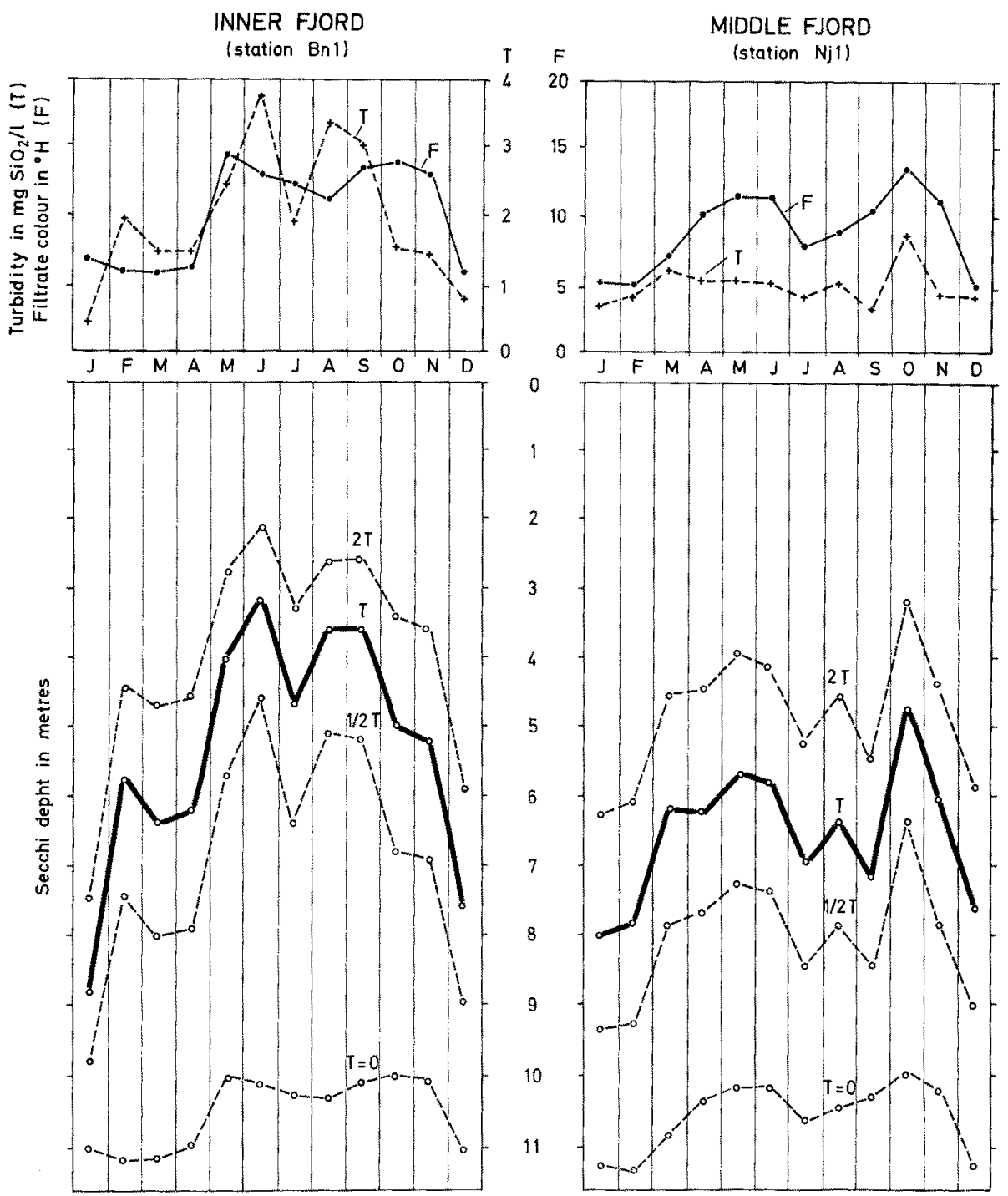

Fig. 6: Transparency as a function of turbidity. Top graphs: measured turbidity (T) and filtrate colour (F).; average values from 1964 to 1965 . Bottom graphs: calculated transparency as Secchi depth - based on formula (1) and the following values: turbidity: alternatively $2 \mathrm{~T}, \mathrm{~T}$, $1 / 2 \mathrm{~T}$ and zero ( $\mathrm{T}$ as shown in the top graphs); filtrate colour: $\mathrm{F}$ (as shown in the top graphs); sun elevation: $\mathrm{O}^{\circ}$; wind force: zero 


\section{POSSIBLE WAYS TO IMPROVE THE PRESENT CONDITIONS}

The recreational quality of the fjord as a whole depends on each of the pollution aspects mentioned; the relative importance of each, however, is still unknown. A detailed evaluation is considered important, but has so far been given little attention in Norway. Two interesting mathematical approaches have lately been published in the United States (KNetsch \& Davis 1967, Davidson, Adams \& Seneca 1966).

In regard to the possibilities of improving the present conditions, the investigation project has supplied a base for the following statements:

(1) The water transparency in the surface layer is a function of turbidity and filtrate colour. Of these two, filtrate colour may be considered unchangeable by human efforts, since it is mainly a product of natural processes. The same holds for that part of turbidity not due to phytoplankton. The only way to increase transparency then is to reduce phytoplankton growth, an undertaking which, according to the project results, seems practicable. The effect of reducing turbidity on surface transparency was estimated by application of the formula (1) shown previously. Figure 6 shows the calculated transmission at two stations based on turbidities and filtrate colours actually measured.

(2) The number of floatables might easily be reduced both by more adequate information and legislation and by simple technical means.

(3) Odour seems mainly to be a local problem connected with sewage outlets and some narrow bays in the fjord. In most cases detrimental odour effects will disappear when the sewage outlets, as is proposed, are removed from the beach region.

(4) The nuisances in the beach region will, in regard to growth and black mould formation, be reduced parallel to the enforced reduction of phytoplankton growth. The other nuisances mainly belong to the same categories as the floatables and should be reduced by similar means.

\section{SUMMARY}

1. The main detrimental consequences of pollution in the fjord are listed on page 477 . Of the ten points listed, three (transparency, floatables and odour) are subjected to some quantitative considerations in the report.

2. The transparency of the surface water was studied (Secchi disc method) as a function of time and location. As expected, transparency varied considerably with seasons. With regard to location, both the degree of protection from the open sea and the distance from main sewage outlets seemed important.

3. The major factors influencing transparency (turbidity and filtrate colour) and the main factors interfering with the Secchi disc readings (sunlight variations and winds) were estimated quantitatively by means of regression analysis.

4. The causes of turbidity in the surface water of the Oslofjord have not been quantitatively investigated. Phytoplankton is assumed to be the dominating factor. An attempt is now being made to confirm this assumption by means of regression analysis. 
5. The dominating cause of filtrate colour in the surface water of the Oslofjord appears to be dissolved colour components of natural origin brought in by the rivers.

6. The problems of floatables on the open waters of the inner fjord seem to be of minor importance. More floating objects were observed in the middle fjord than in the inner fjord. No pertinent investigation was carried out in near shore waters.

7. In the open waters of the inner and middle fjord no bad odour was recorded.

8. The possibilities of improving the recreational quality of the inner fjord are discussed briefly.

\section{LITERATURE CITED}

Danidson, P., Adams, F. G. \& Seneca, J., 1966. The social value of water recreational facilities resulting from an improvement in water quality: The Delaware estuary. In: Water research. Johns Hopkins Press, Baltimore, Md, 175-211.

KNETSCH, J. L. \& Davrs, R. K., 1967. Comparison of methods for recreation evaluation. In: Water research. Johns Hopkins Press, Baltimore, Md, 125-142.

Krümmel, Otтo, 1907. Handbuch der Ozeanographie, Bd. 1. J. Engelhorn, Stuttgart, 256 pp. STRICKLAND, J. D. H., 1958. Solar radiation penetrating the ocean. A review of requirements, data and methods of measurement, with particular reference to photosynthetic productivity. J. Fish. Res. Bd Can. 15, 453-493.

\section{Discussion following the paper by MunTHe-KaAs}

PeArson: Could you tell me if the turbidity in the Oslofjord is affected to any extent by cellulose fibres from the effluent of the pulp and paper mills situated on the shores of the fjord? Investigations on the effect of pulp-mill wastes on the waters of a West-coast Scottish loch have shown that at certain times of the year the concentration of suspended fibres in the water is greater than that of the phytoplankton, and thus must contribute significantly to the total turbidity at such times. I would be interested to hear if you have at any time observed a comparable situation.

Munthe-KaAs: There has been no attempt made to characterize the particles in the waters other than the phytoplankton. We have no knowledge as to what they are. In the draining area of the inner fjord there is only one small cellulose factory, whereas many such factories are discharging their wastes into the middle fjord, directly or via the Drams fjord. Under certain hydrographical conditions the surface water of the middle fjord will enter the inner fjord and influence the water there. I believe, however, that the turbidity effect of cellulose fibers in the inner fjord water is very small.

Koнnke: Können Sie uns Angaben über die vertikale Trübungsverteilung und über vertikale Turbulenzaustauschprozesse im Oslof jord machen?

Munthe-KaAs: Turbidity measurements have regularly been made in all "standard" depths down to the bottom at 9 of the 12 main hydrographical sampling stations. Normally there is a turbidity maximum in the surface layer. Near the city of Oslo the downward decrease is, however, less distinct. Concerning vertical exchange processes in the fjord, some results have been obtained through the hydrographical investigation (as reported by GADE 1968, Helgoländer wiss. Meeresunters. 17, 462). No attempt has so far been made to utilize these results to calculate vertical transports of turbidity. 